\title{
EFFECT OF FAT REPLACER (SIMPLESSE® -100) ON THE QUALITY AND PROPERTIES OF LOW- FAT GOUDA LIKE CHEESE.
}

Mostafa, M.A

Dairy Technology Department, Animal Production Research Institute, Agriculture

Research Center, Dokki, Giza, Egypt.

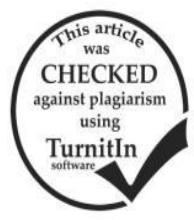

\begin{abstract}
Five batches of Gouda-like cheese were made to study the effect of simplesse ${ }^{\circledR}-100$ at rate $0.18 \mathrm{~g} / \mathrm{L}$ milk on the quality of the resultant Gouda-like cheese during three months of ripening. Three batches of Gouda-like cheese were made from whole fat $(3.5 \%)$, reduced fat $(2.5 \%)$ and low-fat cow's milk (1.5\%). Similarly another two batches of reduced $(2.5 \%)$ and low-fat milk $(1.5 \%)$ were made with addition of fat replacer (Simplesse $\left.{ }^{\circledR}-100\right)$ at a rate of $0.18 \mathrm{~g} /$ litre of milk. Results indicated that cheese treatments made by adding simplesse characterized with a pronounced increase in moisture, total protein and titratable acidity. In addition, these chesses characterized with higher ripening indices (WSN/TP, PTN-SN/TP and NPN/TP) and total volatile fatty acids (TVFA) than the corresponding cheese treatments being made without simplesse ${ }^{\circledR}-100$, when fresh and during storage period. Moreover, results revealed that decreasing fat content of cheese had an obvious effect on chemical composition and ripening indices of the resultant cheese, when fresh and during storage period

Results revealed that decreasing fat content of cheese had a remarkable effect on total viable, proteolytic and lipolytic bacterial counts in the resultant cheeses during ripening period. Addition of simplesse ${ }^{\circledR}-100$ decreased the counts of total viable, proteolytic and lipolytic bacterial in resultant cheese compared with cheese free from simplesse ${ }^{\circledR}-100$ along the ripening period.

Furthermore, addition of simplesse ${ }^{\circledR}-100$ improved the sensory properties of low fat cheese especially its body and texture(T3 and 5) to be near to control one (full-fat cheese) .Also, its more acceptable than chesses made without simplesse ${ }^{\circledR}$ 100 (T2 and T4).
\end{abstract}

Keywords:Cow's milk ,smiplesse ${ }^{\circledR}-100$,chemical composition, ripeningindices.

\section{INTRODUCTION}

Gouda cheese is one of the popular semi- hard Dutch cheeses. Consumption of this cheese in Egypt has been increased in the recent years, and it has been manufactured in some Egyptian dairy factories.

Over the past decade, dietary fat has been linked to risk of diseases such as coronary heart disease, obesity, cancer and blood cholesterol which are related to oxidation of lipid. (Akoh, 1998). This health risk has necessitated the need to improve the consumer awareness and a vivid change in the supply and demand for low fat foods including cheese. Furthermore, Fat plays an important role in the body \& texture and flavour of cheese. Full-fat Gouda cheese characterized by a protein matrix interspersed with fat globules of varying shapes and size. Meanwhile, low- fat cheese tends to have low intensity of taste, typical flavor and hard and grainy texture (Mistry and Anderson, 1993). Low- fat cheese made by conventional methods was of poor functional properties and poor aroma and rubbery body and texture. It could also be observed an appearance of calcium lactate crystals (Rodrigues ,1998). In the light of this many ingredients and different technological strategies have been developed for enhancing quality of low - fat cheese.

Fat replacers are ingredients used to reduce fat content with a substantial decrease of caloric value and at the same time providing some of functional properties of fat. It divided into 2 groups: fat substitutes and fat mimetics .Fat substitutes are non-polar and soluble compounds providing sensory and functional properties of fats to food. However, fat mimetics are polar water soluble substances used to partially replace sensory and functional characteristics of fat. Fat mimetics were reported to improve sensory and functional characteristics of low fat cheese by binding water, and thereby improving texture and yields (Mistry, 2001).
According to a composition fat mimetics consist mainly of micro - particulates protein or carbohydrate -based materials (kavas .etal .,2004). Carbohydrate -based fat replacer are widely used in food processing to improve functional properties that are adversely affected by lowering of fat levels (Zisu and shah ,2005).However ,protein - based mimetics are also employed to replace fat in cheese manufacture .

The objective of this study is to investigate the effect of adding protein-based fat replacer (simplesse- ${ }^{\circledR}$ -100 ) on the quality of low-fat Gouda-like cheese during storage period.

\section{MATERIALS AND METHODS}

Fresh cow's milk was obtained from the herd of Sides experimental station, Animal Production Research Institute. Simplesse ${ }^{\circledR}-100$ a protein -based fat was obtained from CP KLCo , Chicago , II ,USA (it's chemical composition was moisture $40 \%$, ash > $7 \%$ and carbohydrate $39.5 \%$. Salt was obtained from El Naser Company, Alexandria, Egypt. Hansens's powder rennet from Chr. Hansen's laboratories, Copenhagen, Denmark.

Lactococcus lactis subsp. lactis was obtained From Cairo Microbiological Resource Center (MIRCEN), faculty of Agriculture, Ain Shams Univ, Egypt. Tryptone Glucose Extract agar medium code CM 127 (TG EA) and Nutrient agar medium were bought from Oxoid division of Oxoid LTD, London, UK. Five batches of Gouda-like cheese were made as follow's:

Treatment 1: made from full - fat $(3.5 \pm 0.1 \%)$ cow's milk and served as control (T1).

Treatment 2: made from reduced fat milk $(2.5 \pm 0.1 \%)$ without adding simpless-100 (T2)

Treatment 3: made from reduced fat milk $(2.5 \pm 0.1 \%)+$ simplesse-100 0.18g/l milk (T3) 
Treatment 4: made from low - fat milk $(1.5 \pm 0.1 \%)$ without adding simplesse $-100(\mathrm{~T} 4)$

Treatment 5: made from low - fat milk $(1.5 \pm 0.1 \%)$ +simplesse $-1000.18 \mathrm{~g} / \mathrm{l}$ milk (T5).

Milk of all treatments was pasteurized at $74^{\circ} \mathrm{c}$ /20sec cooled to $32{ }^{\circ} \mathrm{C}$ and $0.02 \% \mathrm{CaCl}_{2}$ was added. -: simplesse 100 was added to milk. The rest steps of manufacturing process were carried out according to (scott , 1981) .Cheese of all treatments were ripened at $8-10{ }^{\circ} \mathrm{c}$ for 3 months at $85 \%$ relative humidity. Cheese samples were periodically taken at $0,1,2$ and 3 months of ripening for chemical, microbiological and sensory evaluation. Three replicates of this were done.

Moisture, fat, titratable acidity and total protein were determined according to ling (1963). PH value were measured using a calomel glass electrode $\mathrm{PH}$ meter model HANNA instruments H 18424. Salt was determined according to method of Simov(1980). Water soluble nitrogen was determined according the method described by kucoo and Fox(1982). Non- protein nitrogen was estimated according to IDF (1993). Phosphotungstic acid (5\%) and soluble nitrogen were determined according to Jarret , etal (1982). Total volatile fatty acids was estimated with method described by kosikowski(1982) .

Total viable count was determined according to American Public Health Association method (APHA, 2004), proteolytic bacteria was determined according to Sharaf( 1970), lipolytic bacteria was determined with method described by Davis( 1955)

Organoleptic properties scored by the staff members Dairy Technology Department, Animal Production Research Institute according to Pappas, etal (1996)..Scoring scale, flavor (50), body \& texture(40), appearance(10).

The general liner models procedure of Statistical Analysis System (SAS) was used to analyze the data. Analysis of variance for all cheese samples were performed to determined differences between samples. One-way randomized complete block design and least significant differences (L.S.D) were adopted in the resultant (SAS 1990).

\section{RESULTS AND DISCUSSION}

It is clear from Table (1) decreasing the fat in cow's milk cheese to $2.5 \%$ (reduced - fat milk) and $1.5 \%$ (low -fat milk) had a significant effect on the chemical composition of the resultant Gouda - like cheese, when fresh and during storage period. This reduction led to increasing the moisture and protein contents in the resultant Cheese. The moisture and protein of fresh full-fat cheese (T1) were 41.75 and $21.25 \%$ respectively and the corresponding values of reduced -fat cheese (T2) were 44.65 and $26.70 \%$ and low fat cheese (T4) were 47.32 and $30.22 \%$, in order .Addition of Simplesse ${ }^{\circledR}-100$ had a significant effect on moisture contents. Moreover, moisture contents were 46.88 and $49.87 \%$ for fresh treatments (T3 and T5) containing Simplesse $®-100$, respectively, being 42.53 and $44.99 \%$ for the same treatments, after 3 months of ripening, in order. The addition of Simplesse $\AA-100$ markedly increased the moisture contents of this treatments (T3 and T5) as compared with control .Generally, it was noted that the moisture contents of low fat cheese made with Simplesse ${ }^{\circledR}-100$ were higher than that in the control either fresh and during ripening .These results agreed with those reported by Mc Mahon etal. (1996) . They mentioned that low-fat cheese containing whey - based fat replacer had 2.2 to $2.3 \%$ higher moisture content than, the corresponding one free from fat replacer. In addition, simpelesse was observed as microparticles embedded within the casein matrix, which allow greater moisture retention and curd synersis was retreated during cheese making as a result of water being bound directly to the fat replacers, or fat replacer may interfere with shrinkage of the casein matrix, thus lowering the diving force involved in expelling water from the curd particles. Moreover, the results revealed that inverse relationship between the fat content of cheese milk and protein of cheese. This relationship was continued along the storage period. Cheese samples contained Simplesse ${ }^{\circledR}-100$ possessed highest values of protein compared to control cheese. The same trend was noticed, also by (Guinea etal, 1998 and Sahan etal, 2008).

It is clear from Table (1) the addition of Simplesse ${ }^{\circledR}-100$ had significant effect on F/DM of the resultant cheese when fresh and during storage period. Control cheese (T1) had higher F/DM content than other treatments. Whereas, low fat Gouda like cheese made with Simplesse ${ }^{\circledR}-100$ (T3 and T5) had slight higher fat content than corresponding low fat Gouda like cheese made without Simplesse ${ }^{\circledR}-100$ (T2 and T4).Similar trends was obtained by EL-Aidie (2005). Who mentioned that addition fat replacers to Edam cheese had no pronounced effect on the F/DM contents of the resultant cheeses compared to the control one, during ripening period .Moreover, as the ripening period progressed, the F/DM of all cheese treatments were gradually increased reaching to maximum values after three months of ripening. This could be attributed to the reduction of its moisture content throughout the storage period.

Results, also, showed that salt contents of cheese contained Simplesse ${ }^{\circledR}-100$ were slightly higher than cheese without Simplesse $®-100$ when fresh and during storage period.

From data in Table (2), it could be noticed that adding Simplesse ${ }^{\circledR}-100$ to milk cheese had remarkable effect on titratable acidity (TA) .Cheese made with Simplesse (T3 and T5) had higher TA than corresponding cheese made without Simplesse ${ }^{\circledR}-100$ (T2and T4). These results might be due to the higher moisture content (higher water activity), which enhances the growth of cheese microflora and subsequently developing acidity .Similar results were reported by Luecy and Gorry (1993).In addition, the TA of all cheese treatments had the same trend of increasing along storage period .The trend of the changes in $\mathrm{pH}$ values of all treatments was opposite to that acidity .It decreased gradually in all cheese treatments during storage period .Furthermore, it can be observed that the reduction of cheese fat content, led to the decrease in 


\section{J. Food and Dairy Sci., Mansoura Univ., Vol. 7 (1), January, 2016}

the TA(T2 and T4) compared with the control(T1) when fresh and during storage period. On the other hand,

there is an opposite trend was observed when simplesse was added (T3 and T5).

Table (1). Effect of adding simplesse- 100 to cheese milk on the chemical composition of low - fat Gouda- like cheese during storage period.

\begin{tabular}{|c|c|c|c|c|c|c|}
\hline \multirow{3}{*}{$\begin{array}{l}\text { Ripening period } \\
\text { (months) }\end{array}$} & \multicolumn{5}{|c|}{ Treatments* } & \multirow[t]{3}{*}{ L.S.D } \\
\hline & \multirow{2}{*}{$\begin{array}{c}\text { Full-fat (control) } \\
\text { T1 }\end{array}$} & \multicolumn{2}{|c|}{ Reduced-fat } & \multicolumn{2}{|c|}{ Low- fat } & \\
\hline & & T2 & T3 & $\mathbf{T 4}$ & T5 & \\
\hline \multicolumn{6}{|l|}{ Moisture (\%) } & \multirow{7}{*}{0.3719} \\
\hline Fresh & 41.75 & 44.65 & 46.88 & 47.32 & 49.87 & \\
\hline 1 & 40.40 & 42.96 & 44.96 & 45.93 & 48.02 & \\
\hline 2 & 39.50 & 41.18 & 43.75 & 44.77 & 46.89 & \\
\hline 3 & 38.8. & 40.26 & 42.53 & 42.68 & 44.99 & \\
\hline Mean & $40.11^{\mathrm{e}}$ & $42.26^{\mathrm{d}}$ & $44.53^{\mathrm{c}}$ & $45.18^{\mathrm{b}}$ & $47.44^{\mathrm{a}}$ & \\
\hline \multicolumn{6}{|l|}{ Fat/DM (\%) } & \\
\hline Fresh & 48.51 & 40.34 & 41.60 & 30.00 & 31.12 & \multirow{5}{*}{8.5302} \\
\hline 1 & 49.63 & 41.17 & 42.70 & 30.70 & 32.13 & \\
\hline 2 & 50.65 & 41.98 & 42.94 & 31.14 & 32.76 & \\
\hline 3 & 51.30 & 42.75 & 43.47 & 32.80 & 33.81 & \\
\hline Mean & $50.02^{\mathrm{a}}$ & $41.56^{\mathrm{a}}$ & $42.68^{\mathrm{a}}$ & $31.16^{\mathrm{b}}$ & $32.46^{\mathrm{b}}$ & \\
\hline \multicolumn{6}{|l|}{ Total Protein (\%) } & \multirow{6}{*}{1.1767} \\
\hline Fresh & 23.25 & 26.70 & 27.86 & 28.30 & 30.22 & \\
\hline 1 & 25.30 & 27.52 & 29.63 & 29.60 & 31.60 & \\
\hline 2 & 26.63 & 28.44 & 30.83 & 30.83 & 32.37 & \\
\hline 3 & 27.36 & 29.92 & 31.56 & 31.56 & 33.49 & \\
\hline Mean & $25.64^{\mathrm{d}}$ & $28.15^{\mathrm{c}}$ & $29.97^{b}$ & $30.07^{\mathrm{b}}$ & $31.92^{\mathrm{a}}$ & \\
\hline \multicolumn{6}{|l|}{ Salt (\%) } & \multirow{6}{*}{0.2024} \\
\hline Fresh & 2.18 & 2.10 & 2.32 & 2.08 & 2.24 & \\
\hline 1 & 2.67 & 2.58 & 2.68 & 2.54 & 2.65 & \\
\hline 2 & 2.92 & 2.82 & 2.94 & 2.80 & 2.89 & \\
\hline 3 & 3.08 & 2.99 & 3.15 & 2.97 & 3.11 & \\
\hline Mean & $2.71^{\mathrm{a}}$ & $2.62^{\mathrm{a}}$ & $2.77^{\mathrm{a}}$ & $2.60^{\mathrm{a}}$ & $2.72^{\mathrm{a}}$ & \\
\hline
\end{tabular}

T1: Full-fat cheese (control)

T4: low fat cheese $(1.5 \%)$

T2: Reduced fat cheese $(2.5 \%)$
T5: low fat cheese $(1.5 \%)+$ simplesse

Table (2). Effect of adding simplesse ${ }^{\circledR}-100$ on titratable acidity and $\mathrm{pH}$ value of low - fat Gouda- like cheese, during storage period.

\begin{tabular}{|c|c|c|c|c|c|}
\hline \multirow{3}{*}{ Ripening period (months) } & \multicolumn{5}{|c|}{ Treatments } \\
\hline & \multirow{2}{*}{$\begin{array}{c}\text { Full-fat (control) } \\
\text { T1 }\end{array}$} & \multicolumn{2}{|c|}{ Reduced-fat } & \multicolumn{2}{|c|}{ Low- fat } \\
\hline & & T2 & T3 & T4 & T5 \\
\hline \multicolumn{6}{|l|}{ Acidity (\%) } \\
\hline Fresh & 0.82 & 0.76 & 0.95 & 0.74 & 0.90 \\
\hline 1 & 0.99 & 0.94 & 1.08 & 0.92 & 1.10 \\
\hline 2 & 1.26 & 1.23 & 1.46 & 1.15 & 1.39 \\
\hline 3 & 1.50 & 1.68 & 1.93 & 1.53 & 1.89 \\
\hline \multicolumn{6}{|l|}{$\mathrm{pH}$ value } \\
\hline Fresh & 5.61 & 5.72 & 5.53 & 5.80 & 5.73 \\
\hline 1 & 5.54 & 5.65 & 5.56 & 5.67 & 5.58 \\
\hline 2 & 5.49 & 5.51 & 5.47 & 5.61 & 5.53 \\
\hline 3 & 5.24 & 5.22 & 5.15 & 5.27 & 5.20 \\
\hline
\end{tabular}

T4: low fat cheese $(1.5 \%)$

T2: Reduced fat cheese $(2.5 \%)$
T5: low fat cheese $(1.5 \%)+$ simplesse

From the data in Table (3), it could be noticed that adding Simplesse ${ }^{\circledR}-100$ to low - fat Gouda like cheese (T3 and T5) was accompanied by high level of SN/TN, PTA-SN/TN and NPN/TN. In addition, the ripening indices decreased as the fat content decreased. Moreover, as the storage period advanced the ripening indices (SN/TN, PTA-SN/TN and NPN/TN \%) gradually increased to reach the maximum values at the end of the storage period. These variations may be due to the higher moisture content, acidity and the action of proteolytic bacteria during storage period. Similar trend were obtained by Shehata et.al.(2004) and Ali (2006).

As can be seen from Table (3) results of ripening indices revealed that there is a direct relationship between the fat content of cheese and its content of TVFA, as the fat content of the cheese increased the 
level of TVFA increased. Addition of Simplesse $®-100$ had a great effect on TVFA. Moreover, cheese containing Simplesse ${ }^{\circledR}-100$ (T3and T5) had higher TVFA contents when fresh and during ripening than control cheese (T1) and low fat Gouda -like cheese (T2and T4) .Sahan etal (2008) stated that addition of fat replacer to kashar cheese increased the liberation of TVFA in the resultant cheese than control and low fat cheese. Also, Fox etal. (2004) reported that during ripening, many starters loose viability and release their intracellular enzymes due to autolysis. These enzymes playing a crucial role in maturing the cheese and participate greatly in proteolysis and lipolysis process. Subsequently, increasing the value of ripening indices and TVFA, along the repining period.

Table (3) Ripening indices of reduced and low-fat Gouda-like cheese as effected by the addition of simpelesse100 to cheese milk, during storage period.

\begin{tabular}{|c|c|c|c|c|c|}
\hline \multirow{3}{*}{$\begin{array}{l}\text { Ripening period } \\
\text { (months) }\end{array}$} & \multicolumn{5}{|c|}{ Treatments } \\
\hline & \multicolumn{2}{|c|}{ Full-fat ( control) } & \multicolumn{2}{|c|}{ Reduced-fat } & Low-fat \\
\hline & T1 & $\mathbf{T 2}$ & T3 & T4 & T5 \\
\hline & \multicolumn{5}{|c|}{ WSN/TN(\%) } \\
\hline Fresh & 8.64 & 7.28 & 7.62 & 6.42 & 7.32 \\
\hline 1 & 9.92 & 8.82 & 8.97 & 7.85 & 8.22 \\
\hline 2 & 11.61 & 9.63 & 10.24 & 8.77 & 9.42 \\
\hline 3 & 12.64 & 10.78 & 11.52 & 9.36 & 10.65 \\
\hline & \multicolumn{5}{|c|}{ PTA-SN/TN(\%) } \\
\hline Fresh & 1.12 & 1.01 & 1.32 & 0.82 & 1.18 \\
\hline 1 & 1.75 & 1.54 & 1.68 & 1.43 & 1.51 \\
\hline 2 & 2.84 & 2.63 & 2.75 & 2.32 & 2.49 \\
\hline \multirow[t]{2}{*}{3} & 3.36 & 2.99 & 3.21 & 2.47 & 2.98 \\
\hline & \multicolumn{5}{|c|}{ NPN/TN(\%) } \\
\hline Fresh & 3.87 & 3.16 & 4.36 & 2.88 & 3.75 \\
\hline 1 & 4.72 & 4.33 & 4.62 & 3.94 & 4.16 \\
\hline 2 & 5.12 & 4.82 & 4.95 & 4.17 & 4.56 \\
\hline \multirow[t]{2}{*}{3} & 5.99 & 4.90 & 5.77 & 4.52 & 5.33 \\
\hline & \multicolumn{5}{|c|}{ Total volatile fatty acids (TVFA)\% } \\
\hline Fresh & 8.07 & 6.9 & 8.18 & 6.6 & 8.12 \\
\hline 1 & 12.8 & 11.8 & 13.34 & 10.9 & 12.9 \\
\hline 2 & 16.6 & 14.6 & 17.14 & 12.2 & 16.8 \\
\hline 3 & 19.4 & 16.7 & 20.21 & 14.3 & 19.9 \\
\hline
\end{tabular}

TVFA: milliliter of $0.1 \mathrm{~N}$ NaoH/100 g cheese.

T1: Full-fat cheese (control) T2: Reduced fat cheese $(2.5 \%)$

fat cheese $(1.5 \%) \quad$ T5: low fat cheese $(1.5 \%)+$ simplesse
T3: Reduced fat cheese $(2.5 \%)+$ simplesse $\quad$ T4: low
Counts of bacteria, yeast and mould present in cheese contribute in a positive manner to the maturation process either directly through their metabolic activity or indirectly through the release of enzymes into the cheese matrix through autolysis._From data in Table (4), it could noticed that counts of total viable (TC), proteolytic and lipolytic bacteria were higher in fresh full-fat cheese (T1) than the other treatments. This reduction was more in low-fat cheese (T3 and T5) than in reduced - fat cheese (T2and T4).This decrease may be due to the variations in chemical composition between full-fat cheese and reduced or low fat cheese. Moreover, the results indicated that there is gradual increase was observed throughout the storage period up to 30 days in all cheese treatments. Then the number of bacteria decreases gradual with storage. The TC of full fat cheese (T1) were $8.5 \mathrm{cfu} \times 10^{7} / \mathrm{g}$ at the beginning of ripening decreased to $7.2 \mathrm{cfu} \times 10^{7} / \mathrm{g}$ at the end of the storage period. Whereas, counts of TC in T2 and T4 were $7.7 \mathrm{cfu} \times 10^{7} / \mathrm{g}$ and $6.8 \mathrm{cfu} \times 10^{7} / \mathrm{g}$ declined to 6.6 cfux $10^{7} / \mathrm{g}$ and $5.2 \mathrm{cfu} \times 10^{7} / \mathrm{g}$. Decreasing the moisture content, increasing acidity and the end products of metabolism process may be participating in this reduction. Similar trends were obtained by Haque et.al.(2007).

On the other hand, addition of Simplesse $-\circledR-100$ resulted in lower counts of these populations in cheese when fresh and during ripening, compared to other treatments. This reduction of bacterial counts was referred to the reduction of water activity because the fat replacer has higher water holding capacity which subsequently affect and inhibiting the bacterial growth. Banwart (1981). The counts of proteolytic and lipolitic bacteria decreased by decreasing the fat content in the cheese when fresh and during storage period. At the ripening period advanced, the proteolytic and lipolitic counts of all treatments gradually increased up to the end of the ripening period. This trend of increase was found to be opposite to that happened in TC. Full-fat cheese (T1) recorded the highest counts, after 3 months of ripening, (118 and $64 \mathrm{CFu} \times 10^{3} / \mathrm{g}$ for proteolytic and lipolytic, in order).The lowest counts were found in low-fat cheese containing Simplesse ${ }^{\circledR}-100$ (T5) .(Gilles and Lawrence, 1973)stated that four parameters influence the gross composition of the cheese, Salt in moisture, non-fat substances, fat in day matter and PH 
value. These parameters in turn influence the environment in which the microorganisms proliferate. The primary environmental factors controlling growth of microorganisms in cheese include water and salt content, $\mathrm{PH}$ value, presence of organic acids and nitrate , redox potential and ripening temperature(Beresford etal ,2001).

Table (4). Effect of adding simplesse-100 to gouda-like cheese milk on the total, proteolytic and lipolytic bacterial counts of the resultant cheese, along the ripening period.

\begin{tabular}{|c|c|c|c|c|c|}
\hline \multirow{3}{*}{$\begin{array}{l}\text { Ripening period } \\
\text { (months) }\end{array}$} & \multicolumn{5}{|c|}{ Treatments } \\
\hline & \multirow{2}{*}{$\begin{array}{c}\text { Full-fat control } \\
T_{1}\end{array}$} & \multicolumn{2}{|c|}{ Reduced-fat } & \multicolumn{2}{|c|}{ Low-fat } \\
\hline & & $\mathbf{T}_{2}$ & $\mathbf{T}_{3}$ & $\mathbf{T}_{4}$ & $\mathbf{T}_{5}$ \\
\hline & \multicolumn{5}{|c|}{ Total bacterial count $\left(\mathrm{CFu} \times 10^{\prime} / \mathrm{g}\right)$} \\
\hline Fresh & 8.5 & 7.7 & 6.7 & 6.8 & 5.6 \\
\hline 1 & 10.4 & 9.5 & 8.5 & 8.8 & 7.3 \\
\hline 2 & 9.1 & 8.8 & 7.2 & 7.3 & 6.2 \\
\hline \multirow[t]{2}{*}{3} & 7.2 & 6.6 & 5.1 & 5.2 & 4.4 \\
\hline & \multicolumn{5}{|c|}{ proteolytic bacterial count ( $\mathrm{CFu} \times 10^{3} / \mathrm{g}$ ) } \\
\hline Fresh & 41 & 36 & 33 & 33 & 30 \\
\hline 1 & 79 & 68 & 63 & 57 & 51 \\
\hline 2 & 99 & 82 & 76 & 66 & 62 \\
\hline \multirow[t]{2}{*}{3} & 118 & 101 & 93 & 85 & 81 \\
\hline & \multicolumn{5}{|c|}{ lipolytic bacterial count $\left(\mathrm{CFu} \times 10^{3} / \mathrm{g}\right.$ ) } \\
\hline Fresh & 28 & 18 & 16.2 & 14.2 & 11 \\
\hline 1 & 49 & 33 & 28.3 & 26 & 22.3 \\
\hline 2 & 57 & 40 & 35 & 33.3 & 30 \\
\hline 3 & 64 & 45 & 40.1 & 36 & 32 \\
\hline $\begin{array}{l}\text { T1: Full-fat cheese (con } \\
\text { T4: low fat cheese (1.5\% }\end{array}$ & \multicolumn{5}{|c|}{ T2: Reduced fat cheese $(2.5 \%) \quad$ T3: Reduced fat cheese $(2.5 \%)+$ simplesse } \\
\hline
\end{tabular}

Significant differences were noticed between the organoleptic properties of full and low fat cheese during storage period. Full -fat Gouda cheese (T1) characterized by smooth body, open texture and clean acid flavor. Moreover, control cheese (T1) gained the highest scores when fresh and during storage period as compared to the other treatments contained or free from simplesse. Awad etal. (2003) reported that no fracture was observed when full -fat Gouda cheese sample compressed in the hand and it was of a pliable body \& texture. On the other hand, low -fat cheese was of the lowest sensory properties among the other treatments, along the ripening period. Its characterized by flat flavour, more firmer body and elastic texture, crumbling under compression force than the control cheese .These results are close with that found by (Madeson \& Ardo, 2001) and (Awad etal 2003).In addition, Drake etal .(2010) showed that differences documented between full-fat and low-fat cheeses, are not due to solely to differences in matrix and flavour release but also to distinct differences in ripening biochemistry, which leads to an imbalance of many flavour contributing compounds.

Results revealed that reduction of cheese fat had a reverse effect on the organoleptic properties of resultant cheese. Furthermore, adding Simplesse ${ }^{\circledR}-100$ has significant effect on organoleptic properties of low fat - Gouda like cheese. Moreover, it improve greatly its sensory attributes "especially body and texture". These results are in line with those reported by Drake etal .(1996) .They stated that the function of simplesse (a whey protein fat replacer ) is decreasing the available hydrophobic sites at the fat /water surface in ripe cheese and did not full substitute the role of fat in aroma and flavour binding capacity. Therefore, data in table (5) show that reduced and low-fat cheese containing simplesse (T3 and T5) had lower score points than fullfat cheese (T1), throughout the ripening period and had higher scores than cheeses free from simplesse (T2 and T4). These results are consistent with that reported by Aryana etal (2001). They stated that fat replacers reduced the continuous protein matrix of low - fat cheese (compact body and firmness) and increased the openness texture of the resultants cheese (smoothness).

As the ripening period progressed the organoleptic properties of all cheeses were improved and enhanced as a result of the chemical and microbiology changes occurred. 
Table (5):-Organoleptic properties of Gouda- like cheese as affected by reducing cheese milk-fat and addition of Simplesse 100, during storage period.

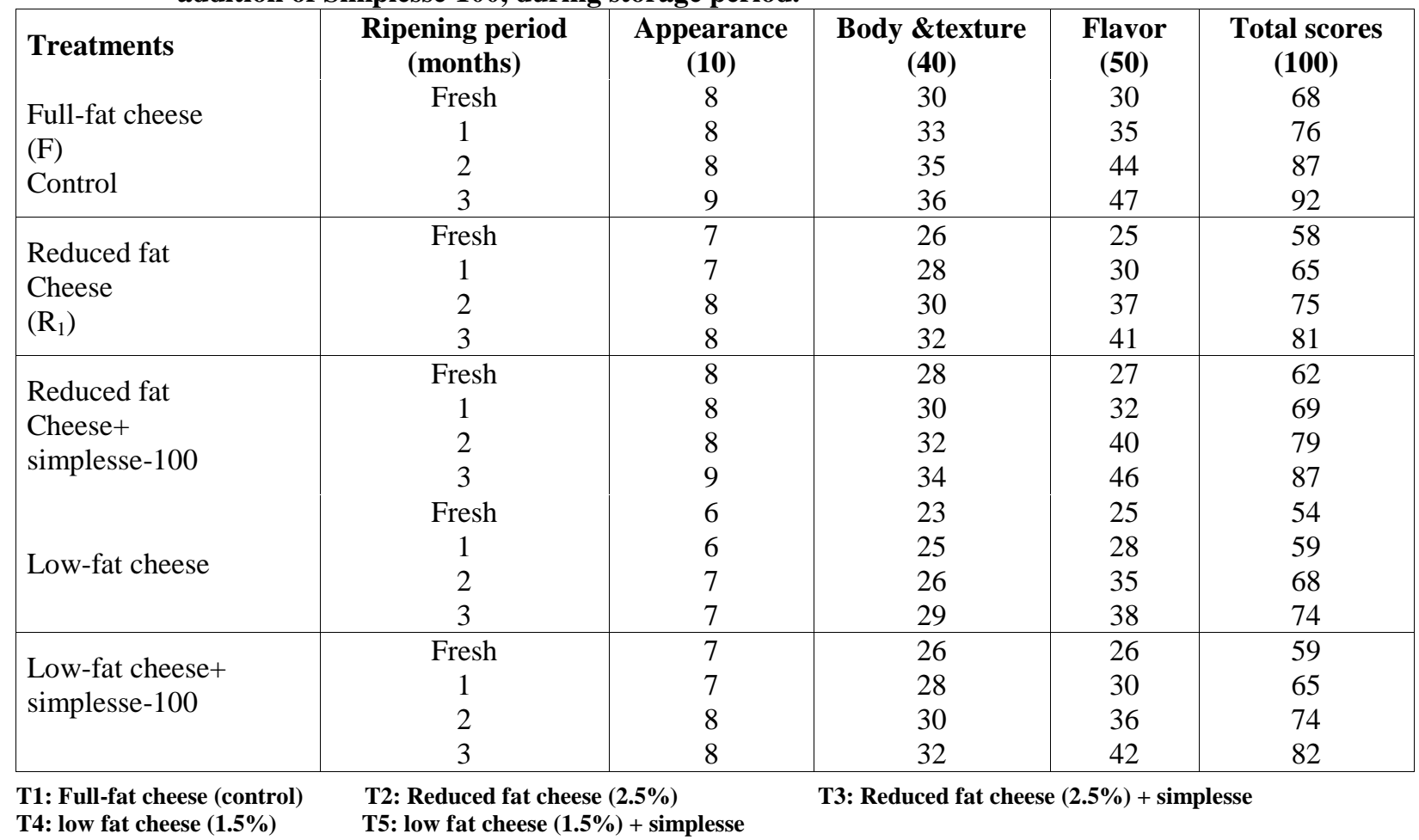

\section{REFERANCES}

Akoh ,C. (1998) Fat replacers .Food Tech.

Ali.M.A(2006). Activity of proteolytic enzymes during the ripening of low-fat Ras cheese. Ph .D. Thesis, Fac of Agric, Minia Univ, cairo, Egypt .

APHA (2004) American Journal of Public Health Association: (2004), Vol $94,9,1549$.

Aryana , K,J;Haque Z.U and Kayanush J.(2001).Effect of commercial fat replacers on the microstructure of low-fat Cheddar cheese .Intern J. Food. Sci. and Tech ., 36(2):169.

Awad S, El-Attar, A. Ayad E.H.E and El-Soba, M (2003) Characteristics of Egyptian market ras cheese. I. Sensory evaluation, rheological Physiochemical properties and microbiological analysis. Egyptian j. Dairy sci. 31:289.

Banwart G.J (1981) Basic Food Microbiology AVI Publishing company INC Westport Connecticut, USA

Beresford, T.P, Fit Zs imons, Brenna N, I and Cogan T.M (2001) Resent advanced in cheese microbiology. Int. Dairy J, 11:259.

Davis, J.G (1955). A Dictionary of Dairing .Publ .Leonard Hill, London England ,USA

Drake, LM.A ;Boylston, T.D. and Swanson, B.G (1996) Fat mimetices in low-fat Cheddar cheese .J. Food Sci ., 61(6): 1267.

Drake, L.M.A.; Miracle, R.E and Mc Mahon D.J. (2010). Impact of fat reduction on Flavour chemistry of Cheddar cheese .J. Dairy Sci. 93 (11)5069.

El-Aidie, A.S. (2005). Improving the quality and microstructure of low-fat Edam cheese made from buffaloe's milk .M. Sc .Thesis, faculty of Agric .Cairo Univ . Egypt.
Fox, P. F.; Mc Sweeny, P.LH. ;Cogn, T.M and Guinee, T, P. (2004) Cheese: chemistry, physics and microbiology $.3^{\text {ed }}$ ED .Vol .1 General aspects .Elsevier Academic press .UK.

Gilles, J. and Lawrence, R.C (1973). The assessment of Cheddar cheese quality by compositional analysis. New Zealand J. of Dairy Sci. And Technol., 8:148.

Guinee , T.P .; Fenelon ,M A .; Mulholland , E.O ;O'Kennedy , B.T .; O'Brien , N. and Reville , W.J (1998) . The influence of milk pasteurization temperature and $\mathrm{PH}$ at curd milling on the composition, texture and maturation of reduced fat Cheddar cheese Int. J. Dairy Tech., 5 (1) : 1-10 .

Haque, Z.U; Kucukoner, E.and Aryana .K . J (2007). Aging - Induced chnges in population of lactoccoci, lactobacilli, and aerobic microorganisms in low-fat and full-fat Cheddar cheese .J. Food Prot., 60:1095.

International Dairy Federation (IDF, 1993). "Milk determination of the nitrogen" (keldahel method and calculation of the crude protein content. IDF standard $20 \mathrm{~B}$. Brussbls ' belgum .

Jarrette .W.D ;Astone .J.W. and Dully .J.R (1982). Simple methods for estimating free amino acid in cheddar cheese. Aust. J. of dairy tech 37:55.

Kavas .G; Oysun , G; kinik O . and Liysal , H (2004 ). Effect of some fat replacers on chemicals, physicals and sensory attributes of low-fat replacers pickled on chemical, physical and sensory attributes of low-fat white picked cheese . Food chemistry 88: (3) 381.

Kosikowski, F.V (1982). Cheese and fermented milk foods. $2^{\text {ed }}$, published by F.V Kosikowski and Associates. New York, USA 


\section{J. Food and Dairy Sci., Mansoura Univ., Vol. 7 (1), January, 2016}

Kuchroo, C, N and Fox P.F (1982.) Soluble nitrogen in cheddar cheese. Comparison of extraction procedures. Milchwissenschaft ,37(6):331.

Ling E.R (1963)." Text Book of Dairy Chemistry "Vol II practical $3^{\text {rd }}$ edition publishers chapman and Hall limited .london

Luccey .J.and Gorry .C. (1993). Effect of Simplesse 100 on the manufacturer of low-fat Cheddar cheese. International Dairy Federation Seminar, Brussels, belgums .page 439

Madeson. J.s and Ardo .Y. (2001). Exploratory study of proteolysis. rheology and sensory properties of Danbo cheese with different fat contents .Int Dairy J ., 11(4-7):423.

McMahon. D, J; Alleyne M.C ; Fife ,R .L and C.J Oberg (1996). Use of fat replacers in low-fat mozzarella cheese .J Dairy. Sci. 79:1911.

Mistry, V. V. (2001).Low fat cheese technology .Int Dairy J.11:413.

Mistry , V, V and Anderson , D,L (1993). Composition and microstructure of commercial full-fat and low-fat cheese . Food Structure, 12:259.

Pappas, C.P Kondly E.; Voustsinas , L .P. and Mallatou $\mathrm{H}$ (1996) Effect of starter level, during time and aging on physiochemical organoleptic and rheological properties of Feta cheese. J of Society of Dairy Tech 49:73 .
Rodriguez, J (1998). Recent advances in the development of low-fat cheeses. Trends in Foods Sci . Technol .,9:249-254

Sahan , N;Yasser , K ;Hayaloglu , A.A ; Karaca , O.B and Kaya ,a. (2008). Influence of fat replacers on chemical composition, texture profiles meltabilty and sensory properties of low-fat Kasar cheese . J .of Dairy Res 75:1.

SAS $^{\circ}$ User's Guide: Statistics. Version 6.0 (1990). SAS Inst., Inc., Cary, NC.

Sharaf , J.M (1970). Recommended methods for the examination of food $2^{\text {nd }}$ public Health Association .Inc ., New York .

Shehata, A.E; El-nawawy , M.A ; El - Kenany , Y.m. and Aumara , I.E (2004) ..Use of Bifido bacteria in Ras cheese production ,II Microbiology properties . The $9^{\text {th }}$ Egyptian Conf. for Dairy Sci and Tech. "Milk and Dairy Products for Healthy Future". The Egyptian International Center for Agric. 563.

Scott, R. (1981). Cheese Making Practice. Applied Science Publisher L.T.D London

Simov, G.U (1980). Technological of milk products, A text Book, Plovidiv .P. 162

Zisu, B and N.P Shah (2005). Texture and functional changes in low-fat Mozzarella cheeses in relation to proteolysis and microstructure as influenced by the use of fat replacers, preacidification and EP starter .Int. Dairy J. ,15 (6-9):957.

\footnotetext{
تأثير أضافة بديل الدهن Simplesse@ - 100 على صفات الجبن المشابه للجبن الجودا المنخفض الدهن

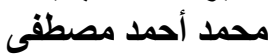
قسم تكنولوجيا الالبان ــمعهد بحوث الانتاج الحيوانى بالدقى ـمركز البحوث الزراعية

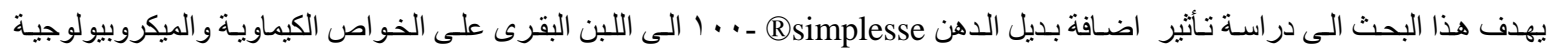

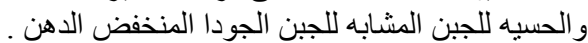

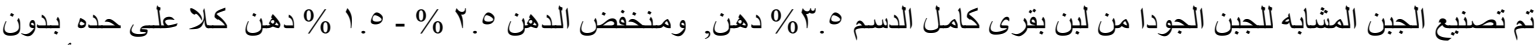

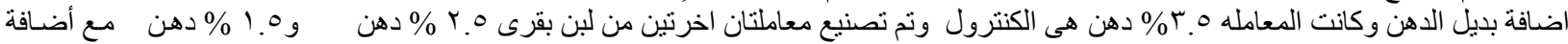

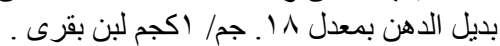

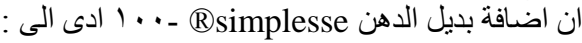

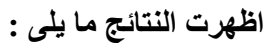

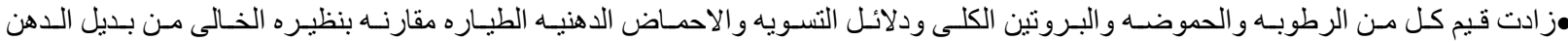
مهimplesse

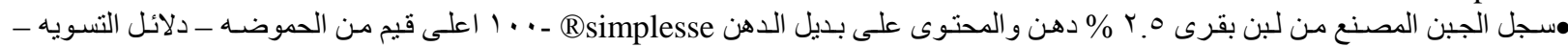

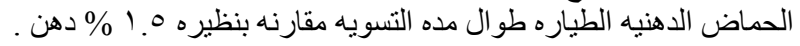

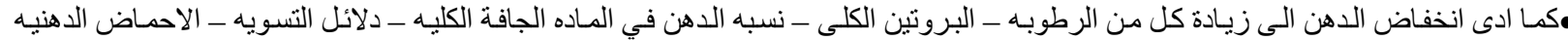

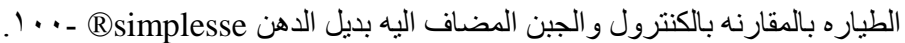

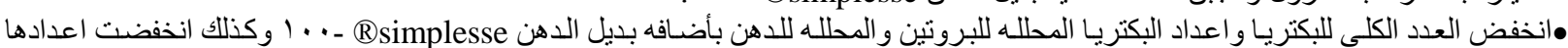

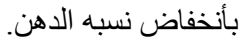

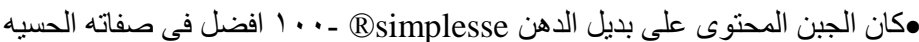

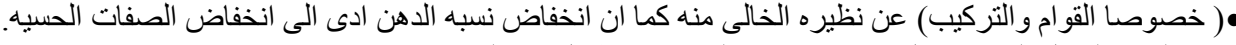
•كان الجبن الكامل الدهن افضل حسيا من باقى المعاملات طو ال مدة التسويه.
} 